Colloque C2, supplément au Journal de Physique III, Volume 5, février 1995

\title{
A New Cu-Based SMA with Extremely High Martensitic Transformation Temperatures
}

J.M. Guilemany, J. Fernández, R. Franch, A.V. Benedetti* and A.T. Adorno*

Metalurgia Física-Cienca dels Materials, Dept. d'Enginyeria Química i Metalurgia, Facultat de Química, Marti i Franquès, 1. E-08028 Barcelona, Spain

* Universidade Estadual Paulista, Instituto de Química, Rua Prof. Francisco Degni. Bairro, Quitandinha, 14800 Araraquara, Brasil

\begin{abstract}
A new series of high temperature copper based shape memory alloys has recently been patented. These alloys contain 8-20 wt\% Al, 1-20 wt\% Ag, 0-2 wt\% of a minor element (preferably $\mathrm{Co}$ ), balance copper. The martensitic start transformation temperatures of these alloys are above $200^{\circ} \mathrm{C}$ and, in some cases, they have good high temperature stability and may be useful in commercial applications where higher operating temperatures than those obtained from $\mathrm{Cu}-\mathrm{Zn}-\mathrm{Al}$ and $\mathrm{Cu}-\mathrm{Al}-\mathrm{Ni}$ shape memory alloys are required.
\end{abstract}

\section{INTRODUCTION}

The shape memory alloys which are industrially used are based upon NiTi, CuZnAl and $\mathrm{CuAlNi}$ to which minor elements such as $\mathrm{Co}, \mathrm{Zr}, \mathrm{Ti}$ are added to control grain growth. The $\mathrm{NiTi}$ and CuAINi series of alloys can be used at temperatures up to $200^{\circ} \mathrm{C}$.

Considerable interest (1-3) has been expressed in the possibility of producing a relatively cheap copper based shape memory alloy with a martensitic transformation temperature above $200^{\circ} \mathrm{C}$. The present work describes the results obtained with a variety $\mathrm{Cu}-\mathrm{Al}$ alloys containing $\mathrm{Ag}$ which show martensitic transformation temperatures well above $200^{\circ} \mathrm{C}$.

\section{EXPERIMENTAL METHOD}

Different $\mathrm{Cu}-\mathrm{Al}-\mathrm{Ag}$ alloy composition have been obtained by melting the pure metals $(99.9 \%)$ in an induction furnace with an inert atmosphere of Ar. Some samples have been heated at $900^{\circ} \mathrm{C}$ for 15 minutes, quenched into water to $100^{\circ} \mathrm{C}$ for 1 minute and, then, cooled in water at room temperature.

Optical and scanning electron microscopy of the as-cast and heat treated specimens were carried out with an ISI SS60 (60 nm resolution) equiped with an EDS detector. Differential Scanning Calorimetry were carried out with a Mettler DSC-30, heating at $10^{\circ} \mathrm{C} / \mathrm{min}$ from 25 to $500^{\circ} \mathrm{C}$. Transformation temperatures were measured when a remarkable change in base line was observed. 


\section{RESULTS AND DISCUSSION}

Table I shows alloy compositions and transformation temperatures for the alloys studied. It can be seen how the martensitic transformation temperatures are, in all cases, higher than $200^{\circ} \mathrm{C}$.

Table I. $\mathrm{Cu}$ based alloy composition (wt\%) and transformation temperatures $\left({ }^{\circ} \mathrm{C}\right)$.

\begin{tabular}{|c|c|c|c|c|c|c||}
\hline \multicolumn{3}{|c|}{ COMPOSITION } & \multicolumn{3}{c|}{ TRANSFORMATION TEMPERATURES } \\
\hline $\mathrm{Al}$ & $\mathrm{Ag}$ & $\mathrm{Co}$ & $\mathrm{M}_{\mathrm{s}}$ & $\mathrm{M}_{\mathrm{f}}$ & $\mathrm{A}_{\mathrm{s}}$ & $\mathrm{A}_{\mathrm{f}}$ \\
\hline 10.9 & 1 & - & 245 & 135 & 290 & 380 \\
\hline 10.7 & 3 & -- & 285 & 140 & 245 & 475 \\
\hline 9.8 & 2.7 & - & 376 & 230 & 281 & 476 \\
\hline 9.7 & 3.2 & -- & 274 & 194 & 306 & 369 \\
\hline 11.2 & 3.8 & 0.7 & 264 & 164 & 309 & 454 \\
\hline 12.8 & 4 & -- & 251 & 186 & 281 & 382 \\
\hline 12.8 & 6 & -- & 230 & 139 & 277 & 441 \\
\hline 10.1 & 14 & -- & 266 & 157 & 273 & 402 \\
\hline 11.3 & 14.9 & -- & 300 & 201 & 289 & 450 \\
\hline
\end{tabular}

Figures 1 and 2 show the DSC curves obtained for the alloys having $11.2 \mathrm{wt} \% \mathrm{Al}, 3.8 \mathrm{wt} \%$ $\mathrm{Ag}$ and $0.7 \mathrm{wt} \% \mathrm{Co}$ (Figure 1) and $9.7 \mathrm{wt} \% \mathrm{Al}$ and $3.2 \mathrm{wt} \% \mathrm{Ag}$ (Figure 2). Similar alloys with higher Ag content exhibit a DSC curve as is shown in Figure 3 ( $11.3 \mathrm{wt} \% \mathrm{Al}, 14.9 \mathrm{wt} \% \mathrm{Ag}$ ).

The $\mathrm{M}_{\mathrm{s}}$ transformation temperatures were found to change from 230 to $376^{\circ} \mathrm{C}$ which implies a significant increase in comparison with conventional $\mathrm{Cu}$-based shape memory alloys. The enthalpy released during heating or cooling is about $10-12 \mathrm{~J} / \mathrm{g}$, higher than that found for $\mathrm{Cu}-\mathrm{Zn}-\mathrm{Al}$ alloys. However, the enthalpy released during the transformation for alloys with a higher Ag content is only between 6 and $9 \mathrm{~J} / \mathrm{g}$.

The martensitic and reverse transformation take place during an average temperature interval of $100-150^{\circ} \mathrm{C}$, hysteresis $\left(\mathrm{A}_{\mathrm{f}}-\mathrm{M}_{\mathrm{s}}\right)$ takes also place in the same interval temperature but in some cases ( $12.8 \mathrm{wt} \% \mathrm{Al}, 6 \mathrm{wt} \% \mathrm{Ag}$ ) an interval of $211^{\circ} \mathrm{C}$ was found.

Figure 4 shows the martensitic structure of the as-cast alloy containing Co. In this case, the cooling is enough to promote martensitic transformation. However, for all the other alloys, the as-cast structure does not show martensitic transformation, as can be seen in Figure 5, corresponding to the alloy with $9.8 \mathrm{wt} \% \mathrm{Al}$ and $2.7 \mathrm{wt} \% \mathrm{Ag}$. The presence of hypoeutectoid $\alpha_{1}$ (fcc) $\mathrm{Cu}$-rich solid solution is found at the grain boundaries, as is to be expected from examination of the ternary equilibrium diagram (4). When heating the alloy at $900^{\circ} \mathrm{C}$, it becomes $B$ which then transforms martensitically on quenching to $100^{\circ} \mathrm{C}$, Figure 6 .

Other phases are present on increasing the Ag content in the alloy. Thus, the alloy having $11.3 \mathrm{wt} \% \mathrm{Al}$ and $14.9 \mathrm{wt} \% \mathrm{Ag}$ has a martensitic structure, after heat treatment, with the presence of the Ag-rich solid solution $\alpha_{2}$ (f.c.c.) and the $\gamma$ (cubic phase) surrounding $\alpha_{2}$, as can be seen in Figure 7. The presence of these phases do not, substantially, change the martensitic transformation temperatures. The small transformation enthalpy found in this alloy is due to the fact that there is less material to transform martensitically. 


\section{CONCLUSIONS}

1.- The $\mathrm{Cu}-\mathrm{Al}-\mathrm{Ag}$ alloys exhibit martensitic transformation temperatures above $200^{\circ} \mathrm{C}$, with an enthalpy about $10-12 \mathrm{~J} / \mathrm{g}$.

2.- On increasing the Ag content $\alpha_{2}$ and $\gamma$ phases appear decreasing the enthalpy obtained during transformation, but they do not affect the martensitic transformation temperatures.

\section{ACKNOWLEDGEMENTS}

The authors wish to thank Professors L. Delaey (in sabbatical year SAB 94-0168) and J. Nutting (in sabbatical year SAB93-0020) for his careful and critical reading of the paper.

\section{REFERENCES}

[1] Lindquist P. G., Wayman C. M., "Shape Memory and Transformation Behavior of Martensitic Ti-Pd-Ni and Ti-Pt-Ni alloys", Engineering Aspects of Shape Memory Alloys. Ed. Butterworth-Heinemann, (1990), 58-68.

[2] Hurtado I., Van Humbeeck J., Delaey L., J. de Physique $I V$, suppl. au J. de Physique III, $1,(1991), 247-252$.

[3] Guilemany J. M., Fernández J., Franch R., Benedetti A. V., Adorno A. T., "Aleaciones Inteligentes con efecto memoria de forma aplicables en un gran intervalo de temperaturas y particularmente a más de $200^{\circ} \mathrm{C} "$, Patent $\mathrm{n}^{\mathrm{9}}$ 9401789, July, (1994).

[4] Adorno A. T., Cilense M., Garlipp W., J. of Mat. Sci. Letters, 8, (1989), 281-284.

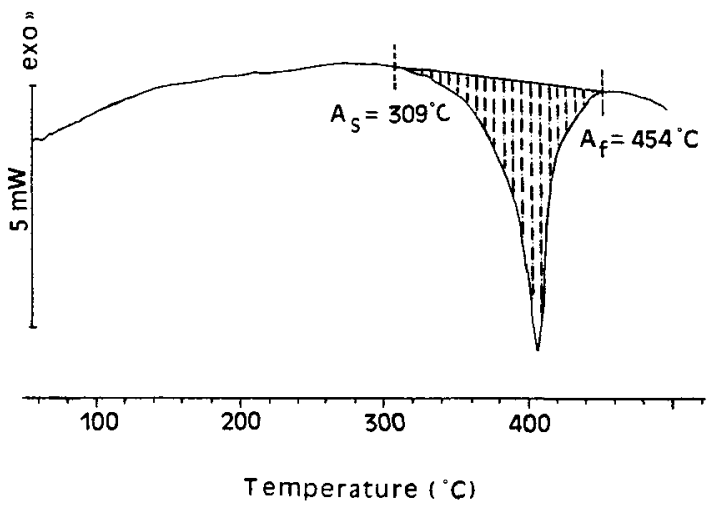

a)

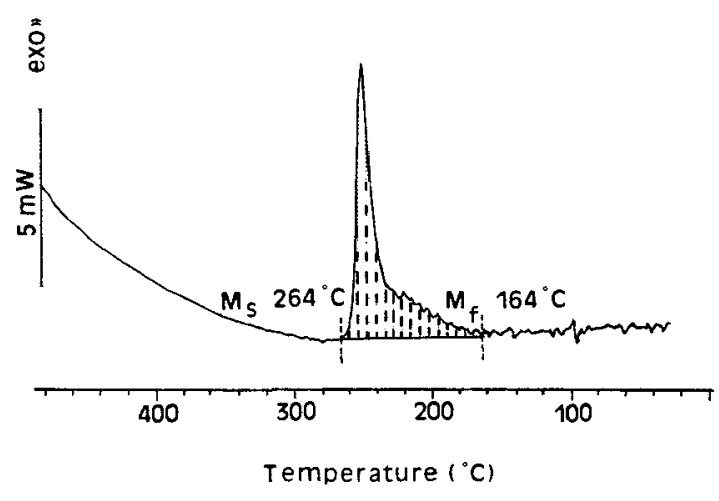

b)

Figure 1 a) and b). DSC curves of the sample with a chemical composition of $11.2 \mathrm{wt} \% \mathrm{Al}$, $3.8 \mathrm{wt} \% \mathrm{Ag}$ and $0.7 \mathrm{wt} \% \mathrm{Co}$, balance $\mathrm{Cu}$. 


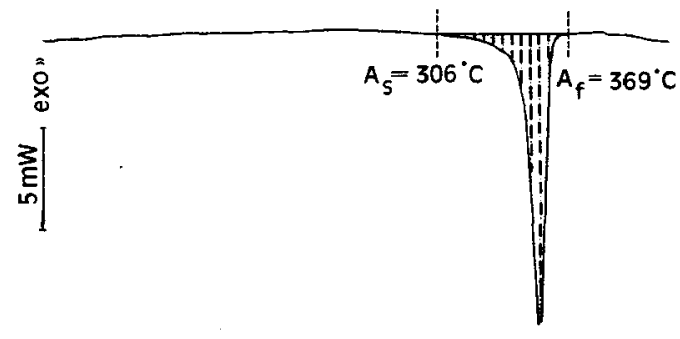

$150 \quad 200250 \quad 300 \quad 350 \quad 400$
Temperature $\left({ }^{\circ} \mathrm{C}\right)$

a)

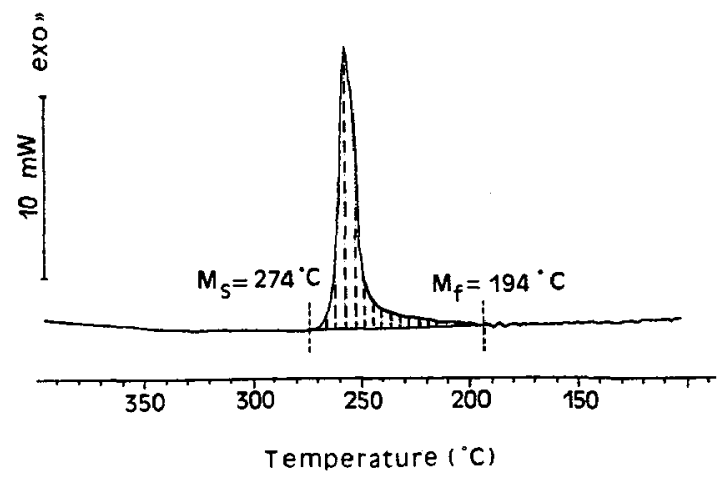

b)

Figure 2 a) and b). DSC curves of the sample with a chemical composition of $9.7 \mathrm{wt} \% \mathrm{Al}$, $3.2 \mathrm{wt} \% \mathrm{Ag}$, balance $\mathrm{Cu}$.

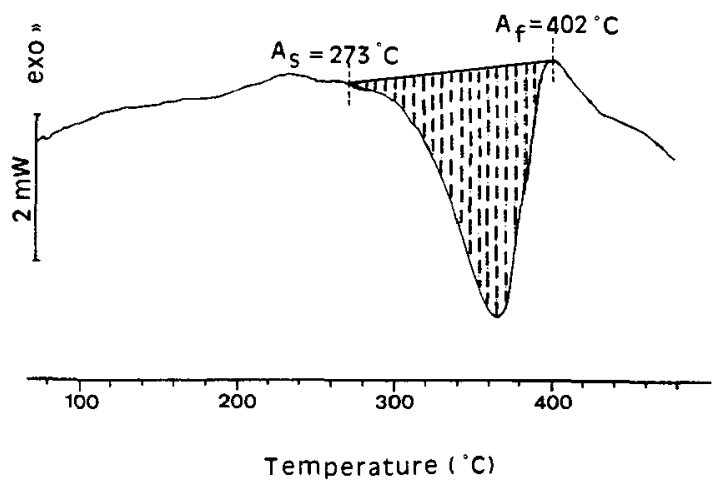

a)

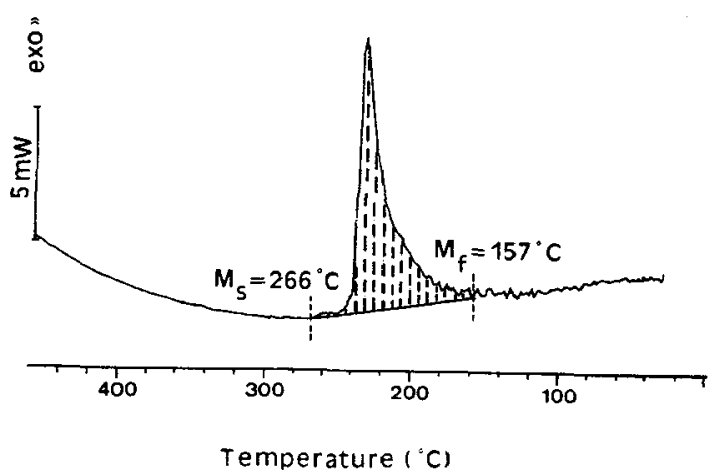

b)

Figure $3 \mathrm{a}$ ) and $\mathrm{b}$ ). DSC curves of the sample with a chemical composition of $11.3 \mathrm{wt} \% \mathrm{Al}$, $14.9 \mathrm{wt} \% \mathrm{Ag}$, balance $\mathrm{Cu}$. 


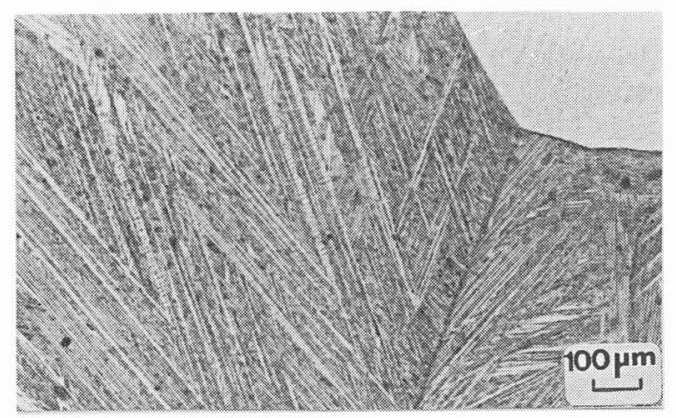

Figure 4. Martensitic structure of the alloy with chemical composition $11.2 \mathrm{wt} \% \mathrm{Al}, 3.8 \mathrm{wt} \% \mathrm{Ag}$ and $0.7 \mathrm{wt} \% \mathrm{Co}$, balance $\mathrm{Cu}$.

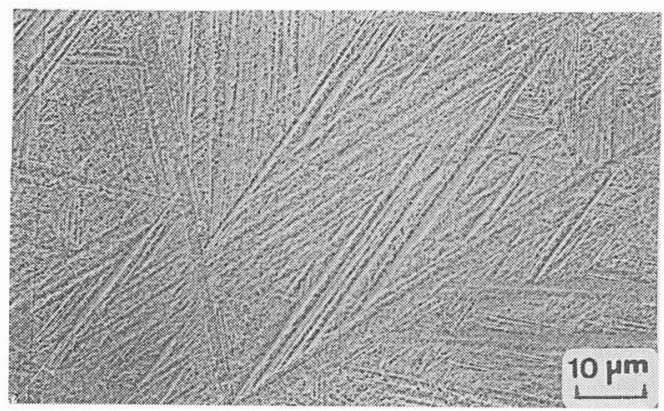

Figure 6. Martensitic structure after thermal treatment of the alloy with $9.8 \mathrm{wt} \% \mathrm{Al}$, $2.7 \mathrm{wt} \% \mathrm{Ag}$, balance $\mathrm{Cu}$.

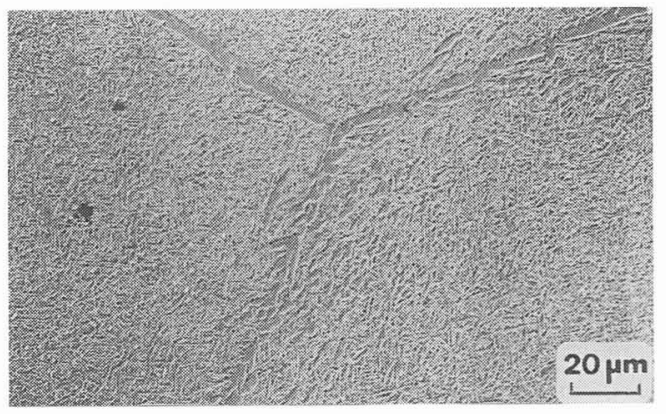

Figure 5. As-cast structure of the alloy with $9.8 \mathrm{wt} \% \mathrm{Al}$ and $2.7 \mathrm{wt} \% \mathrm{Ag}$, balance $\mathrm{Cu}$.

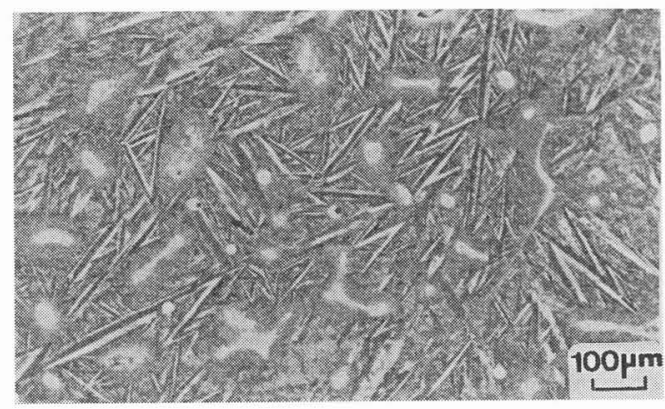

Figure 7. Martensitic, $\alpha_{2}$ and $\tau$ structure of the $\mathrm{Cu}-11.3 \mathrm{wt} \% \mathrm{Al}-14.9 \mathrm{wt} \% \mathrm{Ag}$ after thermal treatment. 